\title{
GEOTHERMAL RESEARCH AT THE PUNA FACILITY
}

DOE I.D. NO. DE-FG-03-85SF15799

FINAL REPORT

\section{PRINCIPAL INVESTIGATORS:}

\author{
Dr. Bill Chen \\ Dr. Patrick Takahashi \\ Dr. Donald Thomas
}

\section{DISCLAIMER}

This report was prepared as an account of work sponsored by an agency of the United States Government. Neither the United States Government nor any agency thereof, nor any of their employees, makes any warranty, express or implied, or assumes any legal liability or responsibility for the accuracy, completeness, or usefulness of any information, apparatus, product, or process disclosed, or represents that its use would not infringe privately owned rights. Reference herein to any specific commercial product, process, or service by trade name, trademark, manufacturer, or otherwise does not necessarily constitute or imply its endorsement, recommendation, or favoring by the United States Government or any agency thereof. The views and opinions of authors expressed herein do not necessarily state or reflect those of the United States Government or any agency thereof. 


\section{DISCLAIMER}

This report was prepared as an account of work sponsored by an agency of the United States Government. Neither the United States Government nor any agency Thereof, nor any of their employees, makes any warranty, express or implied, or assumes any legal liability or responsibility for the accuracy, completeness, or usefulness of any information, apparatus, product, or process disclosed, or represents that its use would not infringe privately owned rights. Reference herein to any specific commercial product, process, or service by trade name, trademark, manufacturer, or otherwise does not necessarily constitute or imply its endorsement, recommendation, or favoring by the United States Government or any agency thereof. The views and opinions of authors expressed herein do not necessarily state or reflect those of the United States Government or any agency thereof. 


\section{DISCLAIMER}

Portions of this document may be illegible in electronic image products. Images are produced from the best available original document. 


\section{Abstract}

A research program has been undertaken in an effort to better characterize the composition and the precipitation characteristics of the geothermal fluids produced by the HGP-A geothermal well located on the Kilauea East Rift zone on the Island of Hawaii. The results of these studies have shown that the chemical composition of the fluids changed over the production life of the well and that the fluids produced were the result of mixing of at least two, and possibly three, source fluids. These source fluids were recognized as: a sea water composition modified by high temperature waterrock reactions; meteoric recharge; and a hydrothermal fluid that had been equilibrated with high temperature reservoir rocks and magmatic volatiles. Although the major alkali and halide elements show clearly increasing trends with time, only a few of the trace transition metals show a similar trend. The rare earth elements, were typically found at low concentrations and appeared to be highly variable with time. studies of the precipitation characteristics of silica showed that amorphous silica deposition rates were highly sensitive to fluid $\mathrm{pH}$ and that increases in fluid pH above about 8.5 could flocculate more than $80 \%$ of the suspended colloidal silica in excess of its solubility. Addition of transition metal salts were also found to enhance the recovery fractions of silica from solution. The amorphous silica precipitate was also found to strongly scavenge the alkaline earth and transition metal ions naturally present in the brines; mild acid treatments were shown to be capable of removing substantial fractions of the scavenged metals from the silica flocs yielding a moderately pure gelatinous by-product. Further work on the silica precipitation process is recommended to improve our ability to control silica scaling from high temperature geothermal fluids or to recover a marketable silica by-product from these fluids prior to reinjection. 
TRACE ELEMENT AND ISOTOPE GEOCHEMISTRY OF GEOTHERMAL FLUIDS, EAST RIFT ZONE, KILAUEA, HAWAII:

FINAL REPORT TO THE DEPARTMENT OF ENERGY

H. B. West ${ }^{1}$, D. C. Gerlach ${ }^{2}$, G. A. Delanoy ${ }^{1}$, and D. M. Thomas ${ }^{1}$

1 Hawaii Institute of Geophysics, University of Hawaii, Honolulu, Hawaii 96822 (U.S.A.).

2 Lawrence Livermore National Laboratory, Livermore, California 94550 (U.S.A.). Now at Charles Evans \& Associates, 301 Chesapeake Drive, Redwood City, California 94063. 


\section{INTRODUCTION}

There have been more than twenty wells drilled into Kilauea over the last thirty years, eight in the last decade (Thomas, 1989), primarily for the purpose of geothermal energy exploration and assessment. Prior to drilling the Scientific Observation Hole Project, which is ongoing, the two most important holes, from a scientific standpoint, were the summit research hole and the Hawaii Geothermal Project [HGP-A] well. The experimental geothermal test well, HGP-A (Fig. 1), was completed in 1976, on the Kilauea ERZ at an elevation of $205 \mathrm{~m}$ (Stone, 1977). This hole reached a depth of $1962 \mathrm{~m}$, but only $1.4 \%$ of the hole was cored $(28 \mathrm{~m})$. Based on hand-sample examination of cutting chips, intense hydrothermal alteration begins at approximately $1350 \mathrm{~m}$ (Stone, 1977).

Fluids were sampled at 1-3 month intervals from the HGP-A well from the time the geothermal generator facility was installed in 1981 until its shutdown in December 1989. These fluids provide a valuable monitor of fluid compositions in the Kilauea geothermal system. Samples were analyzed routinely for major chemical constituents $\left(\mathrm{Na}, \mathrm{Cl}, \mathrm{Ca}, \mathrm{SiO}_{2}\right)$. To better assess the chemistry of these fluids, 55 samples collected between June 23, 1981 and May 18, 1989 were analyzed for trace elements and total dissolved solids and a subset was analyzed for Sr isotopic compositions. The initial results of this study were presented by Gerlach et al. (1989).

The purpose of this report is to present the preliminary findings of our work on the major element, trace element, and isotope geochemistry of geothermal fluids collected from the HGP-A well. The trace elements were analyzed using a relatively new technique, inductively coupled plasma emission mass spectrometry [ICP-MS], that is capable of determining concentrations at the partsper-trillion [pptr] level. The data set obtained for the HGP-A fluid samples using the ICP-MS technique is unusually exhaustive, and may be the most complete set available for geothermal fluids.

\section{SAMPLING AND ANALYTICAL METHODS}

Samples of the HGP-A fluids were collected in clean 1 lit HDPE bottles; both non-acidified, non-filtered and acidified, filtered samples were collected. Hydrochloric acid was added to the fluid samples to prevent silica flocculation. Approximately $8.3 \mathrm{ml}$ of concentrated $\mathrm{HCl}(12.16 \mathrm{M})$ was 
added to each bottle to bring the $\mathrm{pH}$ of the fluids $(\mathrm{pH} \approx 6.85-7.75$ ) down to $\mathrm{pH} \approx 1$.

Abundances of Li, Be, B, Ca, Ti, Cr, Mn, Fe, Co, Cu, Zn, Ge, Ga, As, Se, Br, Rb, Sr, Y, Zr, $\mathrm{Nb}, \mathrm{Mo}, \mathrm{Ag}, \mathrm{Cd}, \mathrm{Sn}, \mathrm{Sb}, \mathrm{Te}, \mathrm{I}, \mathrm{Cs}, \mathrm{Ba}$, rare-earth elements [REE], Hf, Ta, $\mathrm{W}, \mathrm{Au}, \mathrm{Hg}, \mathrm{Tl}, \mathrm{Pb}, \mathrm{Th}$, and $U$ were determined by ICP-MS in the Nuclear Chemistry Division at Lawrence Livermore National Laboratory [LLNL] using analytical techniques developed there. Analyses were done on two instruments, a VG Elemental PlasmaQuad PQ1 and a VG Elemental PlasmaQuad PQ2. Detection limits are in the $p g-\mathrm{g}^{-1}$ range. For elements containing more than one isotope, all principal masses were measured and the mass most free of contributing mass interferences was identified. The masses used to determine concentrations are listed in Table 1. This procedure was important to follow because of the complex chemical matrix of the geothermal solutions. Chlorine complexes, in particular, produced observable contributions to certain masses. Mass contributions from doublycharged ions (e.g., $\mathrm{Ba}^{+2}$ ) appeared insignificant for these fluids.

Concentrations of $\mathrm{SiO}_{2}, \mathrm{Na}, \mathrm{Ca}$, and $\mathrm{Cl}$ were determined at the University of Hawaii by inductively coupled plasma emission spectroscopy [ICP] and atomic absorption spectroscopy [AA]. Total dissolved solids were also determined at the University of Hawaii. ${ }^{87} \mathrm{Sr} /{ }^{86} \mathrm{Sr}$ ratios were determined by thermal ionization mass spectrometry at LLNL.

\section{RESULTS}

A summary of geochemical data for fluids collected during 1981-1989 from the HGP-A Geothermal well is given in Tables 1 and 2. Table 1 includes the range in concentrations for all elements determined by ICP-MS. Table 2 contains data for additional chemical species and elements determined by ICP and AA and for total dissolved solids; also included is a summary of isotopic compositions. All geochemical data are shown in figure 2 and are plotted against the date of sample collection.

\section{Total Dissolved Solids}

The amounts of total dissolved solids in the geothermal fluids increase systematically between 1981 and 1985, after which they were constant. However, some samples have anomalously low total 
dissolved solids that fall off the general trend. At higher $\mathrm{pH}$ values, dissolved silica polymerizes to form colloidal silica, resulting in flocculation and settling (Weres and Tsao, 1981). Because the samples with low total dissolved solids also tend to have lower $\mathrm{SiO}_{2}$ contents than do other samples, silica flocculation probably occurred. The most likely explanation for this result is that samples with anomalously low total dissolved solids were acidified incorrectly during sampling.

\section{Major Elements}

\section{Silicon}

The $\mathrm{SiO}_{2}$ contents of most of the Kilauea geothermal fluid samples are significantly higher than those of seawater but generally are lower than those observed in submarine hydrothermal fluids $(\approx 600-1000 \mathrm{ppm}$ versus $\approx 1100-1320 \mathrm{ppm})$. There is a general positive correlation between $\mathrm{SiO}_{2}$ contents and collection date (Fig. 2). In actuality, $\mathrm{Si}$ may exist as $\mathrm{Si}(\mathrm{OH})_{4}(\mathrm{Stumm}$ and Morgan, 1981) in these fluids, as it does in seawater.

\section{Chlorine, Sodium, Calcium}

The $\mathrm{Cl}$ and $\mathrm{Na}$ abundances of the geothermal fluids are lower than those observed in both seawater and submarine hydrothermal fluids. Calcium abundances range from very low ( $37 \mathrm{ppm})$ to values (400-500 ppm, generally) similar to those of seawater (420 ppm). Abundances of these elemenits increased progressively with time between 1981 and 1986, after which abundances became constant. Thus, they mimic the trend observed for total dissolved solids.

\section{Trace Elements}

\section{Lithium, Rubidium, Cesium}

Rubidium abundances in the geothermal fluids generally range from $\approx 300$ to over $1500 \mathrm{ppb}$, which is significantly higher than either seawater or submarine hydrothermal fluid values. Similarly, Cs abundances in most of these fluids are significantly higher than those in seawater. The $R b$ and Cs contents of the geothermal fluids follow the same temporal trend as does $\mathrm{Na}$, with one notable exception. From early 1988 through 1989, Rb and Cs concentrations increased slightly, whereas $\mathrm{Na}$ abundances were constant. 
Lithium abundances in these fluids range from low values $(\approx 225 \mathrm{ppb})$, similar to those for seawater $(180 \mathrm{ppb})$ to higher values $(\approx 1 \mathrm{ppm})$. However, these abundances are significantly lower than those measured in either basalts or submarine hydrothermal fluids. Lithium abundances increased rapidly from 1981 until mid-1983, when abundances declined slowly. From 1988 on, Li abundances increased slightly, similar to the increase observed for $\mathrm{Rb}$ and $\mathrm{Cs}$.

\section{Titanium, Chromium}

Titanium and chromium abundances in the geothermal fluids are low $(<80 \mathrm{ppb}$ and $<25 \mathrm{ppb}$, respectively), but are much higher than those in seawater (typically $<1 \mathrm{ppb}$ ). Titanium abundances in the fluids increased systematically from 1981 to 1985 , after which they were relatively constant. Samples with anomalously low $\mathrm{Ti}$ also contain low $\mathrm{SiO}_{2}$ and low total dissolved solids. Chromium abundances in the fluids increased systematically from 1981 to $\mathrm{mid}-1985$ and then, in contrast to Ti, decreased progressively through 1989.

\section{Manganese, Iron. Cobalt}

Manganese, iron, and cobalt abundances in the geothermal fluids are much greater than those in seawater, but $\mathrm{Mn}$ and $\mathrm{Fe}$ abundances are significantly lower than those in submarine hydrothermal fluids or in Kilauea basalts. Iron and cobalt display similar temporal trends; abundances of both gradually increased through 1986, after which abundances showed greater shortterm variability but did not systematically increase. In contrast, temporal variations in Mn abundances paralleled those of $\mathrm{Rb}$.

\section{Copper, Zinc}

Copper abundances in the geothermal fluids are much higher than those in seawater but are significantly lower than those in submarine hydrothermal fluids or in Kilauea basalts. In general, $\mathrm{Cu}$ abundances in these fluids increased with time but were highly variable from mid-1984 through 1989.

Zinc abundances in the geothermal fluids are very low; with the exception of two samples, one of which is a low-Si sample, the fluids range from $\approx 1-15 \mathrm{ppb} \mathrm{Zn}$. These values are higher than $\mathrm{Zn}$ 
abundances in seawater but are significantly lower than those in submarine hydrothermal fluids or in Kilauea basalts. $\mathrm{Zn}$ abundances appear to have remained systematically low and constant with time.

\section{Iodine, Bromine}

Iodine abundances in most of the geothermal fluids are much higher than those in seawater. The temporal trend for I differs from those displayed by the alkali metals. Iodine abundances generally increased until mid-1985, after which they generally declined through 1989 . This trend is similar to that show by $\mathrm{Cr}$.

Bromine abundances in the geothermal fluids typically range from $\approx 250-1500 \mathrm{ppb}$, which are significantly lower than those observed for either seawater or submarine hydrothermal fluids. Bromine abundances follow the same temporal trend as does $\mathrm{Na}$.

\section{Strontium, Barium}

Strontium abundances in the geothermal fluids are lower than those in seawater, submarine hydrothermal fluids, or Kilauea basalts. Strontium abundances follow a systematic temporal trend similar to that for $\mathrm{Rb}$, although the initial increase from 1981 to 1985 is much more dramatic. Barium abundances are much higher than those in seawater or submarine hydrothermal fluids but are significantly lower than those in Kilauea basalts. With time, Ba abundances in the fluids increase and concomitantly become more variable.

\section{Rare Earth Elements, Yttrium}

Rare earth element abundances in the geothermal fluids are higher than those in seawater but they are orders of magnitude lower than those observed in submarine hydrothermal fluids. For many of the samples, REE abundances were near the detection limit. Eu abundances increased with time, but were highly variable. No other REE displayed any systematic temporal variation. $Y$ abundances in the fluids are low $(<50 \mathrm{pptr})$ and similar to those in seawater. $Y$ abundances appear to have increased generally with time but, like Eu, were highly variable. 
For many of the samples, $\mathrm{Zr}, \mathrm{Hf}, \mathrm{Nb}$, and $\mathrm{Ta}$ abundances in the geothermal fluids were near the detection limit. With the exception of three samples, $\mathrm{Zr}$ abundances in the geothermal fluids are $<0.5 \mathrm{ppb}$ and are similar to or slightly higher than seawater abundances $(0.03 \mathrm{ppb})$. Hafnium, niobium, and tantalum abundances in the fluids are also low and approach seawater values. There does not appear to have been any systematic temporal variation in the abundances of these elements. Hafnium and tantalum abundances, in particular, varied substantially.

\section{Molybdenum, Tungsten}

Molybdenum abundances in the geothermal fluids $(<10 \mathrm{ppb}$, with the exception of one sample) are similar to or lower than those in seawater but are significantly lower than abundances in typical Kilauea basalt. Unlike the abundances of other elements that display systematic temporal variations, Mo abundances decreased progressively from at least early-1982 through 1989.

Tungsten abundances in the fluids range from seawater values to about an order of magnitude higher than seawater values. Similar to Mo, W abundances appear to have decreased over the same time interval, although there is significantly more variability in the data.

\section{Arsenic, Selenium, Tellurium}

Arsenic, selenium, and tellurium abundances in the geothermal fluids are extremely variable. For the vast majority of samples, As and Se concentrations are higher than those in seawater but are substantially lower than those in typical Kilauea, basalt. In contrast to the relatively restricted range in As observed for the HGP-A fluids, As concentrations in geothermal fluids from various settings span a large range (<0.1 ppm to $\approx 50 \mathrm{ppm}$; Ballantyne and Moore, 1988). Tellurium concentrations in seawater are not well-constrained; Te abundances in the fluids are slightly lower than those in typical Kilauea basalt.

\section{Gallium, Germanium, Tin, Antimony, Thallium}

Gallium, germanium, tin, antimony, and thallium abundances in the geothermal fluids generally are higher than those in seawater, but are substantially lower than those in typical Kilauea basalt. The abundances of these elements in submarine hydrothermal fluids have not been estab- 
lished adequately.

Gallium abundances are variable but appear to increase roughly with time. In contrast, Ge abundances in the fluids were constant over the entire collection period. The three samples with anomalously low $\mathrm{Ga}$ and $\mathrm{Ge}$ also have low $\mathrm{SiO}_{2}$ and low total dissolved solids. The result for $\mathrm{Ge}$ is not surprising since both $\mathrm{Ge}$ and $\mathrm{Si}$ occur naturally in the same valance state $(+4)$ and have similar atomic radii.

The majority of samples contain less than $\approx 0.2 \mathrm{ppb} \mathrm{Sn}$ and, like $\mathrm{Zn}$ abundances, $\mathrm{Sn}$ abundances appear to have remained systematically low and constant with time. Antimony and thallium abundances are low ( $\mathrm{Sb}<2.5 \mathrm{ppb}$, with the exception of one sample; $\mathrm{Tl}<3.5 \mathrm{ppb}$ ) and variable, and do not appear to have changed systematically with time.

\section{Ruthenium, Rhodium, Rhenium, Osmium, Iridium}

Little is known about the distribution of the siderophile elements $R u, R h, R e, O s$, and $I r$ in most terrestrial materials due to their extremely low abundances. Due to the relatively large analytical uncertainties associated with determining these elements by ICP-MS, they are not reported in tables 1 and 3. Of these elements, $\mathrm{Rh}(\approx 0.07-1.83 \mathrm{ppb})$ and $\mathrm{Ru}(8 \mathrm{pptr}$ to $1.3 \mathrm{ppb})$ are the most abundant in the geothermal fluids. Iridium, Rhenium, and Osmium abundances in the fluids generally are below 30 pptr. Of these elements, only $\mathrm{Rh}$ displays any systematic temporal correlation. Rh abundances increased systematically until 1985, after which they were relatively constant. This behavior is similar to that observed for Co.

\section{Cadmium, Mercury, Silver, Gold, Platinum, Palladium}

The abundances of $\mathrm{Cd}, \mathrm{Hg}, \mathrm{Ag}, \mathrm{Au}, \mathrm{Pt}$, and $\mathrm{Pd}$ in the geothermal fluids are near the detection limit. Abundances of these elements in the fluids are similar to or slightly higher than those in seawater but are significantly lower than abundances in typical basaltic rocks. With the exception of two samples, the geothermal fluids contain $<0.75 \mathrm{ppb} \mathrm{Cd}$. A few samples contain elevated $\mathrm{Hg}$ abundances (i.e., 1-13 ppb). $\mathrm{Cd}, \mathrm{Hg}, \mathrm{Ag}, \mathrm{Au}$, and $\mathrm{Pt}$ abundances appear to have remained systematically low and constant with time, similar to what is observed for $\mathrm{Zn}$. Pd abundances are more variable, but also show no systematic variation with time. 


\section{Lead, Thorium, Uranium}

Lead abundances in the geothermal fluids are greater than those in seawater and fall within the range observed for submarine hydrothermal fluids. Between 1981 and $1986, \mathrm{~Pb}$ concentrations in the geothermal fluids varied substantially, ranging from $\approx 5-80 \mathrm{ppb}$. Between 1986 and $1988, \mathrm{~Pb}$ abundances were significantly less variable (all samples contained $<\approx 15 \mathrm{ppb}$ Pb). From early 1988 through 1989, $\mathrm{Pb}$ abundances in the fluids were below the detection (probably $<0.2 \mathrm{ppb}$ ).

Thorium abundances in the geothermal fluids are significantly greater than those in seawater or submarine hydrothermal fluids. These abundances are extremely variable in the fluids and are not correlated with time of collection.

Uranium abundances in the geothermal fluids are near the detection limit. These abundances are lower than those in seawater $(\approx 3.2 \mathrm{ppb})$. With the exception of two samples, the fluids contain $<19$ pptr $U$ and fall within the range observed for submarine hydrothermal fluids $(0.7$ pptr to 3.2 $\mathrm{ppb}$ ). Uranium abundances, like those of $\mathrm{Zn}, \mathrm{Cd}, \mathrm{Ag}$, and $\mathrm{Pt}$, appear to have remained systematically low and constant with time.

\section{Strontium Isotopes}

The ${ }^{87} \mathrm{Sr} /{ }^{86} \mathrm{Sr}$ compositions of the geothermal fluids span a relatively restricted range (0.704783-0.709226). These values are higher than those reported for fresh Kilauea basalts (0.703460.70379; Lanphere et al., 1980; White and Hofmann, 1982; Hofmann et al., 1984; Newsome et al., 1986), but fall within the range for average present-day seawater. From 1981 through early-1983, ${ }^{87} \mathrm{Sr} /{ }^{86} \mathrm{Sr}$ ratios decreased systematically. Although data are limited, it appears that ${ }^{87} \mathrm{Sr} /{ }^{86} \mathrm{Sr}$ ratios of the fluids subsequently increased up to 1985 and then slowly decreased through 1989 . 


\section{DISCUSSION}

The major and trace element compositions of the HGP-A fluids show significant abundance variations and temporal correlations. Total dissolved solids and the abundances of $\mathrm{Na}, \mathrm{Cl}, \mathrm{Ca}, \mathrm{Sr}$, $\mathrm{Ba}, \mathrm{Rb}, \mathrm{Cs}, \mathrm{B}, \mathrm{Li}$, and $\mathrm{Mn}$ increased from 1981, when the generator facility was put into operation, to 1985. After 1985, abundances of these elements remained within $10-15 \%$ of the highest abundances. In contrast, $\mathrm{Pb}$ and $\mathrm{W}$ abundances and $\mathrm{Rb} / \mathrm{Sr}, \mathrm{B} / \mathrm{Li}$, and $\mathrm{Na} / \mathrm{Ca}$ ratios decreased until 1985. $\mathrm{SiO}_{2}$ contents and $\mathrm{Cl} / \mathrm{Br}$ ratios display no clear temporal trends. From 1981 to 1985 , correlations between $\mathrm{Na}$ and other elements (e.g., $\mathrm{Li}, \mathrm{B}, \mathrm{Mn}, \mathrm{Rb}, \mathrm{Sr}, \mathrm{Cs}, \mathrm{Ba}$ ), other inter-element correlations (e.g., Sr, Rb, and Co versus $\mathrm{Mn}$ ), and systematic variations between elemental abundances and several abundance ratios (e.g., $\mathrm{Li}, \mathrm{B}, \mathrm{Na}, \mathrm{Ti}, \mathrm{Mn}, \mathrm{Ge}, \mathrm{Br}, \mathrm{Ba}, \mathrm{B} / \mathrm{Li}, \mathrm{Na} / \mathrm{Ca}, \mathrm{Ba} / \mathrm{Cs}, \mathrm{Rb} / \mathrm{Sr}$ ) suggest mixing between two geochemically distinct components.

A fluid component with high $\mathrm{Rb} / \mathrm{Sr}, \mathrm{Na} / \mathrm{Ca}$, and $\mathrm{B} / \mathrm{Li}$ ratios could have been derived from alteration of basalt by seawater, resulting in an anhydrite-amphibole alteration assemblage. A fluid component with low $\mathrm{Rb} / \mathrm{Sr}, \mathrm{Na} / \mathrm{Ca}$, and $\mathrm{B} / \mathrm{Li}$ ratios could have formed in association with an alteration assemblage dominated by layered silicates. This latter fluid component could represent a hydrothermal component that originated uprift of the HGP-A site on the lower east rift. Such a component could have formed by percolation of meteoric water along fracture and dike swarms trending WNW-ESE. These waters may have originally been driven to depth downrift, and then heated and driven upwards into the more shallow geothermal production area.

Although some inter-ratio correlations suggest mixing between two geochemically distinct reservoirs (e.g., $\mathrm{Na} / \mathrm{Ca}$ versus $\mathrm{Rb} / \mathrm{Sr}$; Fig. 4), the bifurcating trends on plots of other elemental and isotopic ratios (Figs. 5-6) require an additional component. This third component has moderately high ${ }^{87} \mathrm{Sr} /{ }^{86} \mathrm{Sr}$, low $\mathrm{Rb} / \mathrm{Sr}$, and high $\mathrm{Ba} / \mathrm{Cs}$. These geochemical characteristics are typical of basalt that has undergone surface weathering, resulting in loss of alkalies (e.g., Feigenson et al., 1983; Chen and Frey, 1985; West et al., in press). 


\section{Acknowledgements}

We thank G. P. Russ and J. Bazan at LLNL for their generous assistance and access to ICP-MS facilities. Mahalo to Brenda Ikemoto for determining total dissolved solids of the geothermal fluid samples. 


\section{REFERENCES}

Arnorsson, S., Gunnlaugsson, E. and Svavarsson, H., 1983, The Chemistry of Geothermal Waters in Iceland. II. Mineral Equilibria and Independent Variables Controlling Water Compositions: Geochim. Cosmochim. Acta 47, p. 547-566.

Ballantyne, J. M. and Moore, J. N., 1988, Arsenic Geochemistry in Geothermal Systems: Geochim. Cosmochim. Acta 52, p. 475-483.

Berndt, M. E. and Seyfried, W. E., 1990, Boron, Bromine; and Other Trace Elements as Clues to the Fate of Chlorine in Mid-Ocean Ridge Vent Fluids: Geochim. Cosmochim. Acta 54, p. 22352245.

Campbell, A. C., Palmer, M. R., Klinkhammer, G. P., Bowers, T. S., Edmond̄, J. M., Lawrence, J. R., Casey, J. F., Thompson, G., Humphris, S., Rona, P. and Karson, J. A., 1988, Chemistry of Hot Springs on the Mid-Atlantic Ridge: Nature 335, p. 514-519.

Chen, C.-Y. and Frey, F. A., 1985, Trace Element and Isotopic Geochemistry of Lavas from Haleakala Volcano, East Maui, Hawaii: Implications for the Origin of Hawaiian Basalts: J. Geophys. Res. 90, p. 8743-8768.

Chen, C.-Y., Frey, F. A., Garcia, M. O., Dalrymple, G. B. and Hart, S. R., 1991, The Tholeiite to Alkalic Basalt Transition at Haleakala Volcano, Maui, Hawaii: Contrib. Mineral. Petrol. 106, p. 183-200.

Chen, J. H., 1987, U, Th, and Pb Isotopes in Hot Spring on the Juan de Fuca Ridge: J. Geophys. Res. 92, p. 11411-11415:

Chen, J. H., Wasserburg, G. J., Von Damm, K. L. and Edmond, J. M., 1986, The U-Th-Pb Systematics in Hot Springs on the East Pacific Rise at $21^{\circ} \mathrm{N}$ and Guaymas Basin: Geochim. Cosmochim. Acta 50, p. 2467-2479.

Edmond, J. M., Von Damm, K. L., McDuff, R. E. and Measures, C. I., 1982, Chemistry of Hot Springs on the East Pacific Rise and their Effluent Dispersal: Nature 297, p. 187-191.

Feigenson, M. D., Hofmann, A. W. and Spera, F. J., 1983, Case Studies on the Origin of Basalt II. The Transition from Tholeiitic to Alkalic Volcanism on Kohala Volcano, Hawaii: Contrib. Mineral. Petrol. 84, p. 390-405.

Gerlach, D. C., West, H. B., Thomas, D. M., Delanoy, G. A. and Ikemoto, B. N., 1989, Trace Element Geochemistry of Geothermal Fluids, East Rift Zone, Kilauea, Hawaii: EOS 70, p. 1397.

Govindaraju, K., 1989, 1989 Compilation of Working Values and Sample Description for 272 Geostandards: Geostandards Newsletter 13, p. 1-113.

Hofmann, A. W., Feigenson, M. D. and Raczek, I., 1984, Case Studies on the Origin of Basalt: III. Petrogenesis of the Mauna Ulu Eruption, Kilauea, 1969-1971: Contrib. Mineral. Petrol. 88, p. 24-35.

Lanphere, M. A., Dalrymple, G. B. and Clague, D. A., 1980, Rb-Sr Systematics of Basalts from the Hawaiian-Emperor Volcanic Chain: Init. Repts. DSDP 55, p. 695-706.

Li, Y.-H., 1982, A Brief Discussion on the Mean Oceanic Residence Time of Elements: Geochim. Cosmochim. Acta 46, p. 2671-2675.

Michard, A. and Albarede, F., 1986, The REE Content of Some Hydrothermal Fluids: Chem. Geol. 55, p. $51-60$.

Michard, G., Albarede, F., Michard, A., Minster, J.-F. Charlou, J. L. and Tan, N., 1984, Chemistry of Solutions from the $13^{\circ} \mathrm{N}$ East Pacific Rise Hydrothermal Site: Earth Planet. Sci. Lett. 67, p. 297-307.

Newsom, H. E., White, W. M., Jochum, K. P. and Hofmann, A. W., 1986, Siderophile and Chalcophile Element Abundances in Oceanic Basalts, $\mathrm{Pb}$ Isotope Evolution and Growth of the Earth's Core: Earth Planet. Sci. Lett. 80, p. 299-313.

Piepgras, D. J. and Wasserburg, G. J., 1985, Strontium and Neodymium Isotopes in Hot Springs on the East Pacific Rise and Guaymas Basin: Earth Planet. Sci. Lett. 72, p. 341-356.

Stone, C., 1977, Chemistry, Petrography, and Hydrothermal Alteration of Basalts from Hawaii Geothermal Project Well-A, Kilauea, Hawaii: M.S. Thesis, University of Hawaii, 84 p.

Stumm, W. and Morgan, J. J., 1981, Aquatic Chemistry, Wiley, 780 p.

Thomas, D. M., 1989, Hydrothermal Systems in Hawaii: in The Geology of North America Volume N. The Eastern Pacific Ocean and Hawaii, p. 271-277.

Veizer, J., 1989, Strontium Isotopes in Seawater Through Time: Ann. Rev. Earth Planet. Sci. 17, p. 141-167. 
Weres, O. and Tsao, L., 1981, Chemistry of Silica in Cerro Prieto Brines: Geothermics 10, p. 255276.

West, H. B., Garcia, M. O., Gerlach, D. C. and Romano, J., 1992, Geochemistry of Tholeiites from Lanai, Hawaii: Contrib. Mineral. Petrol. (in press).

White, W. M. and Hofmann, A. W., 1982, Sr and Nd Isotope Geochemistry of Oceanic Basalts and Mantle Evolution: Nature 296, p. 821-825. 


\section{FIGURE CAPTIONS}

Figure 1. Map of the Kilauea east rift zone showing the location of the HGP-A well, groundwater wells, and deep geothermal exploration wells (from Thomas, 1989).

Figure 2. Compositions of geothermal fluids from the HGP-A well plotted against the date of sample collection. All samples were collected between 1981 and 1990.

Figure 3. ${ }^{87} \mathrm{Sr} /{ }^{86} \mathrm{Sr}$ versus the date of sample collection for geothermal fluids from the HGP-A well. All samples were collected between 1981 and 1990.

Figure 4. $\mathrm{Rb} / \mathrm{Sr}$ versus $\mathrm{Na} / \mathrm{Ca}$ for geothermal fluids from the HGP-A well.

Figure 5. $\mathrm{Rb} / \mathrm{Sr}$ versus $\mathrm{Ba} / \mathrm{Cs}$ for geothermal fluids from the HGP-A well.

Figure $6 .{ }^{87} \mathrm{Sr} /{ }^{86} \mathrm{Sr}$ versus $\mathrm{Na} / \mathrm{Ca}$ for geothermal fluids from the HGP-A well. 
Table 1. Summary of geochemical data for fluids collected during 19811989 from the HGP-A Geothermal well, East Rift Zone, Kilauea, Hawaii. Concentrations of all elements determined by ICP-MS and given in ppb.

\begin{tabular}{|c|c|c|c|c|}
\hline & & Con & ions & \\
\hline & Mass & LQw & High & Range \\
\hline $\mathbf{L i}$ & 7 & 0.32 & 1036 & 1035.7 \\
\hline $\mathrm{Be}$ & 9 & 0.022 & 0.121 & 0.099 \\
\hline B & 10 & 96 & 2771 & 2675 \\
\hline $\mathrm{Ca}$ & 44 & 22414 & 342836 & 320422 \\
\hline $\mathrm{Ti}$ & 49 & 2.1 & 76.6 & 74.5 \\
\hline $\mathrm{Cr}$ & 52 & 3.2 & 20.5 & 17.3 \\
\hline $\mathrm{Mn}$ & 55 & 2.0 & 373 & 371 \\
\hline $\mathrm{Fe}$ & 57 & 19 & 1445 & 1426 \\
\hline Co & 59 & 0.033 & 0.951 & 0.918 \\
\hline $\mathrm{Cu}$ & 65 & 2.8 & 86 & 83.2 \\
\hline $\mathrm{Zn}$ & 66 & 1.3 & 172 & 170.7 \\
\hline $\mathrm{Ga}$ & 71 & 0.48 & 2.30 & 1.82 \\
\hline $\mathrm{Ge}$ & 73 & 3.5 & 21.7 & 18.2 \\
\hline As & 75 & 0.09 & 9.49 & 9.40 \\
\hline $\mathrm{Br}$ & 81 & 66.8 & 1473 & 1406.2 \\
\hline $\mathrm{Se}$ & 82 & 0.9 & 11.2 & 10.3 \\
\hline $\mathbf{R b}$ & 85 & 8.0 & 1555 & 1547 \\
\hline $\mathrm{Sr}$ & 88 & 252.3 & 6466 & 6213.7 \\
\hline$Y$ & 89 & 0.006 & 0.049 & 0.043 \\
\hline $\mathrm{Zr}$ & 90 & 0.034 & 6.81 & 6.776 \\
\hline $\mathrm{Nb}$ & 93 & 0.018 & 0.039 & 0.021 \\
\hline Mo & 96 & 0.43 & 34.3 & 33.87 \\
\hline $\mathrm{Ag}$ & 107 & 0.049 & 10.89 & 10.841 \\
\hline $\mathrm{Cd}$ & 111 & 0.09 & 25.0 & 24.01 \\
\hline Sn & 118 & 0.19 & 3.64 & 3.45 \\
\hline $\mathrm{Sb}$ & 121 & 0.02 & 7.17 & 7.15 \\
\hline $\mathrm{Te}$ & 125 & 0.20 & 5.02 & 4.82 \\
\hline I & 127 & 6.8 & 310 & 303.2 \\
\hline Cs & 133 & 0.01 & 21.0 & 21.09 \\
\hline $\mathrm{Ba}$ & 135 & 11.1 & 5447 & 5436 \\
\hline $\mathrm{La}$ & 139 & 0.004 & 41.44 & 41.436 \\
\hline $\mathrm{Ce}$ & 140 & 0.006 & 0.194 & 0.188 \\
\hline Pr & 141 & 0.008 & 0.082 & 0.074 \\
\hline $\mathrm{Nd}$ & 146 & 0.029 & 0.218 & 0.189 \\
\hline Sm & 147 & 0.030 & 0.335 & 0.305 \\
\hline $\mathrm{Eu}$ & 151 & 0.010 & 0.480 & 0.470 \\
\hline $\mathrm{Gd}$ & 157 & 0.054 & 0.398 & 0.344 \\
\hline $\mathrm{Tb}$ & 159 & 0.005 & 0.027 & 0.022 \\
\hline Dy & 163 & 0.023 & 0.094 & 0.071 \\
\hline Ho & 165 & 0.005 & 1.640 & 1.635 \\
\hline $\mathrm{Er}$ & 166 & 0.016 & 0.096 & 0.080 \\
\hline $\mathrm{Tm}$ & 169 & 0.004 & 0.534 & 0.530 \\
\hline $\mathrm{Yb}$ & 171 & 0.084 & 0.178 & 0.094 \\
\hline Hf & 178 & 0.021 & 0.141 & 0.120 \\
\hline $\mathrm{Ta}$ & 181 & 0.009 & 0.057 & 0.048 \\
\hline W & 184 & 0.11 & 1.36 & 1.25 \\
\hline $\mathrm{Au}$ & 197 & 0.036 & 0.840 & 0.804 \\
\hline $\mathrm{Hg}$ & 202 & 0.41 & 13.1 & 12.7 \\
\hline $\mathrm{Tl}$ & 205 & 0.018 & 3.32 & 3.30 \\
\hline $\mathrm{Pb}$ & 206 & 0.1 & 79.8 & 79.7 \\
\hline Th & 23 & 0.011 & 0.044 & 0.033 \\
\hline $\mathrm{U}$ & 238 & 0.001 & 0.963 & 0.962 \\
\hline
\end{tabular}


Table 2. Summary of additional geochemical data for fluids collected during 1981-1989 from the HGP-A Geothermal well, East Rift Zone, Kilauea, Hawaii. Elemental concentrations (in ppm, unless indicated otherwise) determined by ICP and AA.

\begin{tabular}{lrrr} 
& \multicolumn{2}{c}{ Compositions } & \\
& \multicolumn{1}{c}{ Low } & High & Range \\
$\mathrm{TDS}^{1}$ & 0.2021 & 35.4234 & 35.2213 \\
$\mathrm{SiO}_{2}$ & 67 & 1112 & 1045 \\
$\mathrm{Na}$ & 121 & 7911 & 7790 \\
$\mathrm{Ca}$ & 37.1 & 683.0 & 645.9 \\
$\mathrm{Cl}$ & 3290 & 12780 & 9490 \\
& & & 0.000331 \\
${ }^{87} \mathrm{Sr} /{ }^{86} \mathrm{Sr}^{2}$ & 0.704783 & 0.705114 & \\
1 & TDS = total disolved solids (in mg-g & \\
2 & Determined at Lawrence Livermore National Laboratory. \\
\hline
\end{tabular}


Table 3. Comparison of geochemical data for fluids from the HGP-A Geothermal well with other data. $\mathrm{SiO}_{2}$, $\mathrm{Na}, \mathrm{Ca}$, and $\mathrm{Cl}$ are given in ppm; all other elements are in ppb, unless indicated otherwise.

\begin{tabular}{|c|c|c|c|c|}
\hline & $\underline{H G P}-A$ & $\underline{\text { Seawater }}^{1}$ & Basalt $^{3}$ & $\underline{\text { Submarine }}^{4}$ \\
\hline $\mathrm{SiO}_{2}$ & $67-1112^{\#}$ & $4.3^{\#}$ & $233437 \#$ & $1093-1322$ \\
\hline $\mathrm{Na}^{2}$ & $121-7911^{\#}$ & $10800 \#$ & $16766^{\#}$ & $9932^{5}=$ \\
\hline $\mathrm{Ca}$ & $37-683 \#$ & $420 \#$ & $81476 \#$ & $625 \#$ \\
\hline $\mathrm{Ca}^{*}$ & $22-343 \#$ & $420 \#$ & & \\
\hline $\mathrm{Cl}$ & $3290-12780 \#$ & $18800 \#$ & 92 & $17337^{5}$ \\
\hline $\mathrm{Li}$ & $0.32-1036$ & 180 & 4600 & $6427^{5}$ \\
\hline $\mathrm{Be}$ & $0.022-0.121$ & 0.0002 & 1100 & $0.1352^{5 \%}$ \\
\hline B & $96-2771$ & 4440 & 2500 & $5405^{5 \neq}$ \\
\hline $\mathrm{Ti}$ & $2.1-76.6$ & 1 & $16220 \#$ & \\
\hline $\mathrm{Cr}$ & $3.2-20.5$ & 0.3 & $289 \#$ & \\
\hline $\mathrm{Mn}$ & $2-373$ & 0.04 & $1300 \#$ & $56257^{5}=$ \\
\hline $\mathrm{Fe}$ & $19-1445$ & 2 & $86420 \#$ & $85446^{5}=$ \\
\hline Co & $0.033-0.951$ & 0.002 & $45 \#$ & \\
\hline $\mathrm{Cu}$ & $2.8-86$ & 0.2 & $136 \#$ & $22+1^{5 \div}$ \\
\hline $\mathrm{Zn}$ & $1.3-172$ & 0.3 & $105^{\#}$ & $6930^{5}=$ \\
\hline Ga & $0.48-2.30$ & 0.03 & $21 \#$ & \\
\hline $\mathrm{Ge}$ & $3.5-21.7$ & 0.007 & 1640 & \\
\hline As & $0.09-9.49$ & 1.8 & 400 & \\
\hline $\mathrm{Br}$ & $66.8-1473$ & $67^{\#}$ & 710 & $62.3-337^{*}$ \\
\hline $\mathrm{Se}$ & $0.9-11.2$ & 0.1 & 74 & \\
\hline $\mathrm{Rb}$ & $8-1555$ & 120 & $11^{\#}$ & $13.4-1160$ \\
\hline $\mathrm{Sr}$ & $252-6466$ & 8000 & 403\# & $87-8674$ \\
\hline Y & $0.006-0.049$ & 0.0013 & $27.6 \#$ & \\
\hline $\mathrm{Zr}$ & $0.034-6.81$ & 0.03 & $179 \#$ & \\
\hline $\mathrm{Nb}$ & $0.018-0.039$ & 0.01 & $19 \#$ & \\
\hline Mo & $0.43-34.3$ & 10 & 1020 & \\
\hline $\mathrm{Ag}$ & $0.049-10.89$ & 0.04 & 55 & \\
\hline $\mathrm{Cd}$ & $0.09-25.0$ & 0.07 & 69 & \\
\hline $\mathrm{Sn}$ & $0.19-3.64$ & 0.01 & $6.2 \#$ & \\
\hline $\mathrm{Sb}$ & $0.02-7.17$ & 0.15 & 160 & \\
\hline $\mathrm{Te}$ & $0.20-5.02$ & - & 6.4 & \\
\hline I & $6.8-310$ & 60 & - & \\
\hline $\mathrm{Cs}$ & $0.01-21.0$ & 0.4 & 130 & \\
\hline $\mathrm{Ba}$ & $11.1-5447$ & 20 & $139 \#$ & $17.2-42.6$ \\
\hline La & $0.004-41.44$ & 0.003 & 15.8 & $23 z-375$ \\
\hline $\mathrm{Ce}$ & $0.006-0.194$ & 0.001 & $39 \#$ & $228-1960$ \\
\hline $\operatorname{Pr}$ & $0.008-0.082$ & 0.0006 & $5.7 \not$ & \\
\hline $\mathrm{Nd}$ & $0.029-0.218$ & 0.003 & $25.2 \ddot{\#}$ & $70-1143$ \\
\hline $\mathrm{Sm}$ & $0.030-0.335$ & 0.0005 & $6.2^{\#}$ & $8-614$ \\
\hline $\mathrm{Eu}$ & $0.010-0.480$ & 0.0001 & $2.06 \#$ & $19-810$ \\
\hline Gd & $0.054-0.398$ & 0.0007 & $6.4 \#$ & $12-270$ \\
\hline $\mathrm{Tb}$ & $0.005-0.027$ & 0.0001 & $0.96 \#$ & \\
\hline Dy & $0.023-0.094$ & - & $5.2 \#$ & $8.3-162$ \\
\hline Ho & $0.005-1.640$ & 0.0002 & $0.99 \#$ & \\
\hline $\mathrm{Er}$ & $0.016-0.096$ & 0.0008 & $2.4 \#$ & $4.4-69$ \\
\hline$T \mathrm{~m}$ & $0.004-0.534$ & 0.0002 & $0.33 \#$ & \\
\hline $\mathrm{Yb}$ & $0.084-0.178$ & 0.0008 & $2.02 \%$ & $4.6-50$ \\
\hline $\mathrm{Hf}$ & $0.021-0.141$ & 0.007 & $4.38 \#$ & \\
\hline Ta & $0.009-0.057$ & 0.002 & $1.23 \#$ & \\
\hline W & $0.11-1.36$ & 0.1 & 270 & \\
\hline $\mathrm{Au}$ & $0.036-0.840$ & 0.004 & 1.6 & \\
\hline $\mathrm{Hg}$ & $0.41-13.1$ & 0.005 & 5.6 & \\
\hline TI & $0.018-3.32$ & 0.01 & 580 & \\
\hline $\mathrm{Pb}$ & $0.1-79.8$ & 0.002 & 2600 & $0.0135-87.4$ \\
\hline $\mathrm{Th}$ & $0.011-0.044$ & 0.00006 & 1080 & $0.00021-0.00^{-7}$ \\
\hline${ }^{87} \mathrm{Sr} /{ }^{86} \mathrm{Sr}$ & $\begin{array}{c}0.001-0.963 \\
0.704783-0.705114\end{array}$ & $\begin{array}{r}3.2 \\
0.709226^{2}\end{array}$ & $\begin{array}{r}420 \\
0.70347^{6}\end{array}$ & $\begin{array}{r}0.0007-3.22 \\
0.703252-0.709109^{5}\end{array}$ \\
\hline
\end{tabular}


Table 3 (cont.). Comparison of geochemical data for fluids from the HGP-A Geothermal well with other data. $\mathrm{SiO}_{2}, \mathrm{Na}, \mathrm{Ca}$, and $\mathrm{Cl}$ are given in ppm; all other elements are in $\mathrm{ppb}$, unless indicated otherwise.

Average seawater ( $\mathrm{Li}, 1982)$.

Average present-day seawater (Vezier, 1989).

Basalt BHVO-1, Kilauea, Hawaii (Govindaraju, 1989).

Submarine hydrothermal fluids (Edmond et al., 1982; Michard et al., 1984; Chen et ai., 1986; Chen, 198\%: Michard and Albarede, 1986; Berndt and Seyfried, 1990).

5 Submarine hydrothermal fluids, East Pacific Rise (Piepgras and Wasserburg, 1985; Campbell et al., 1988)

6 Chen et al. (1991).

Determined by ICP-MS.

\# ppm. 




Figure 1. Map of the Kilauea east rift zone showing the location of the HGP-A well, groundwater wells, and deep geothermal exploration wells (from Thomas, 1989). 

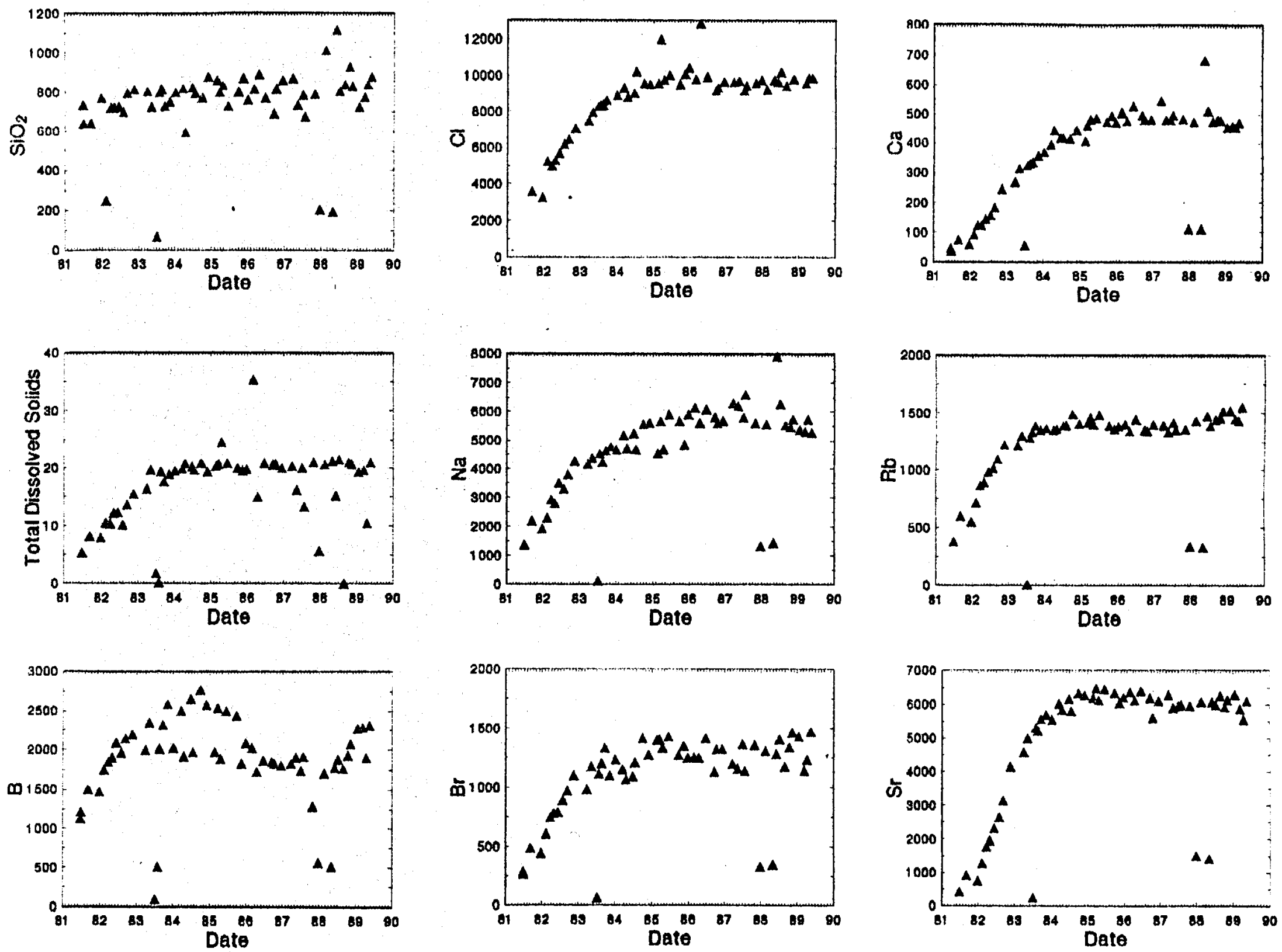

Figure 2. Compositions of geothermal fluids from the HGP-A well plotted against the date of sample collection. All samples were collected between 1981 and 1990. 

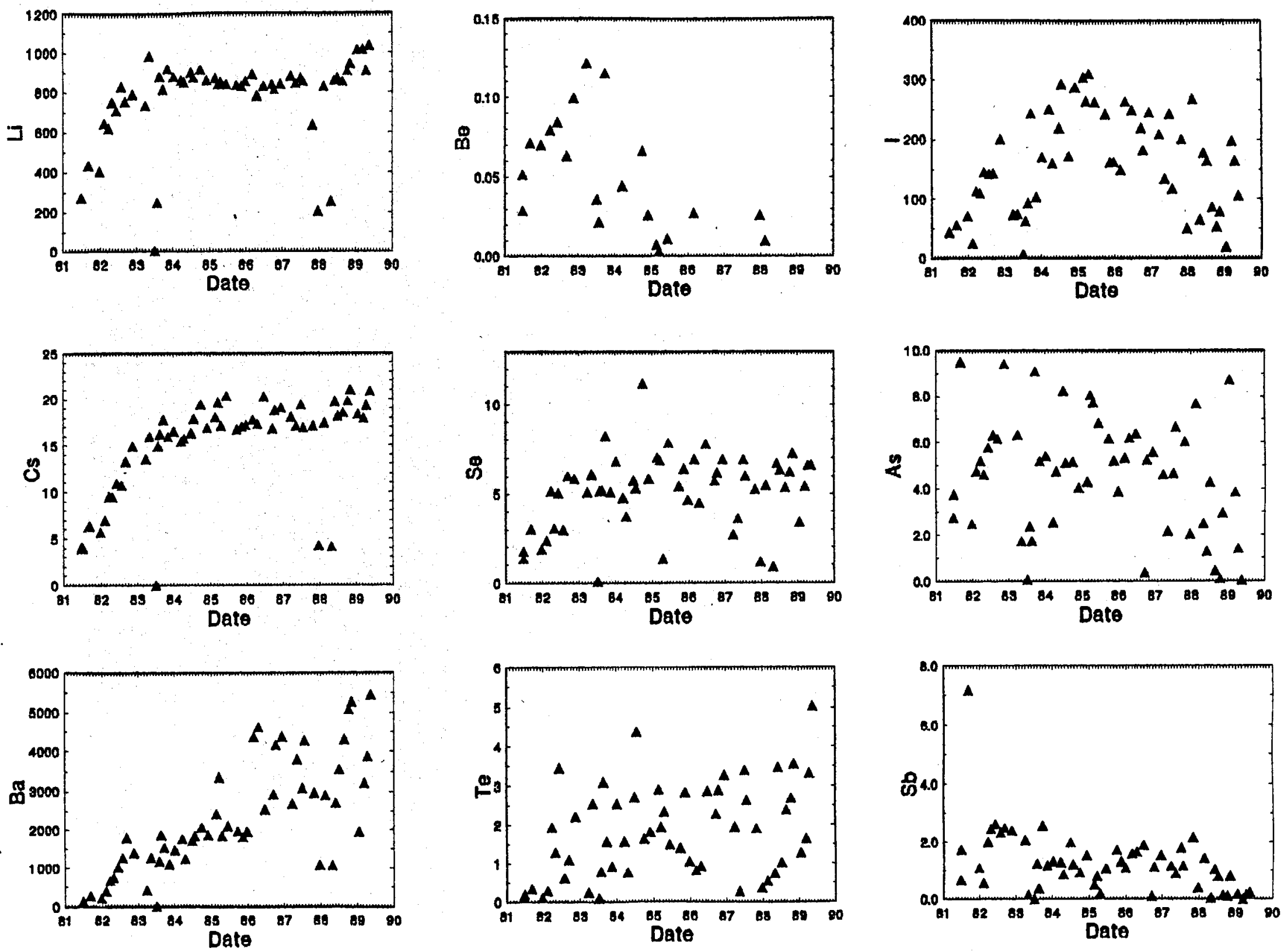

Figure 2 (cont.). Compositions of geothermal fluids from the HGP-A well plotted against the date of sample collection. All samples were collected between 1981 and 1990 . 

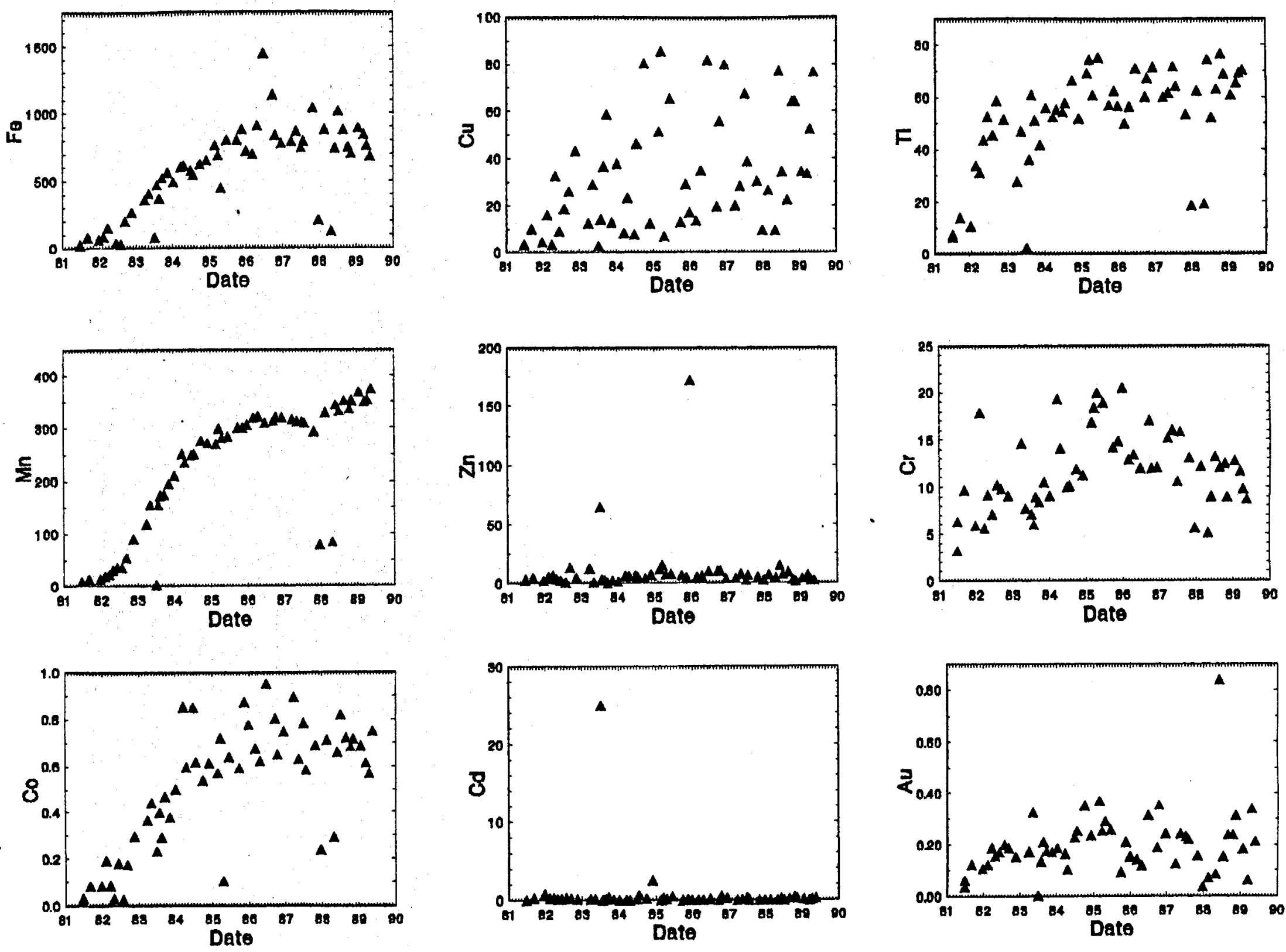

Figure 2 (cont.). Compositions of geothermal fluids from the HGP-A well plotted against the date of sample collection. All samples were collected between 1981 and 1990. 

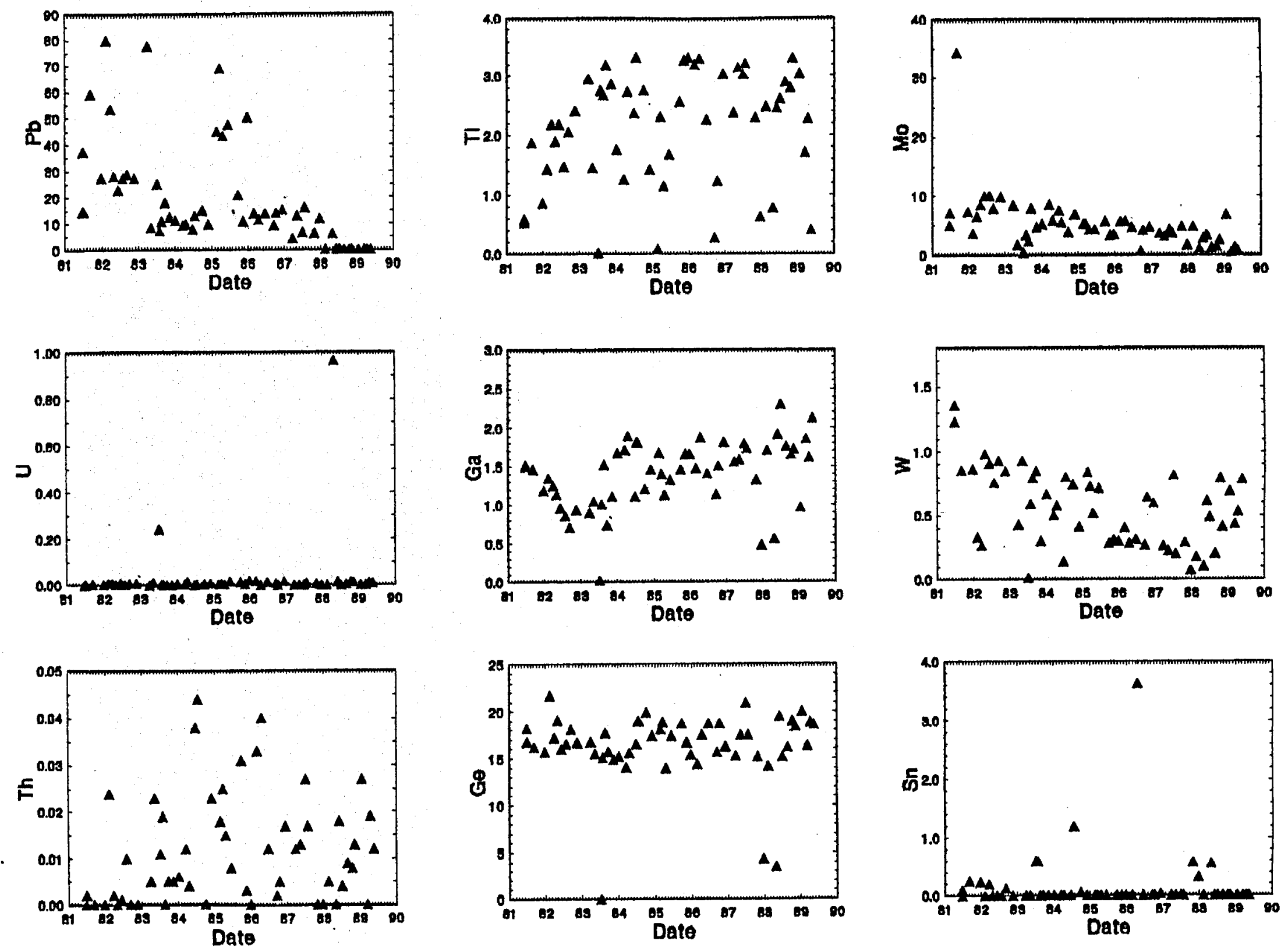

Figure 2 (cont.). Compositions of geothermal fluids from the HGP-A well plotted against the datc of sample collection. All samples were collected between 1981 and 1990. 

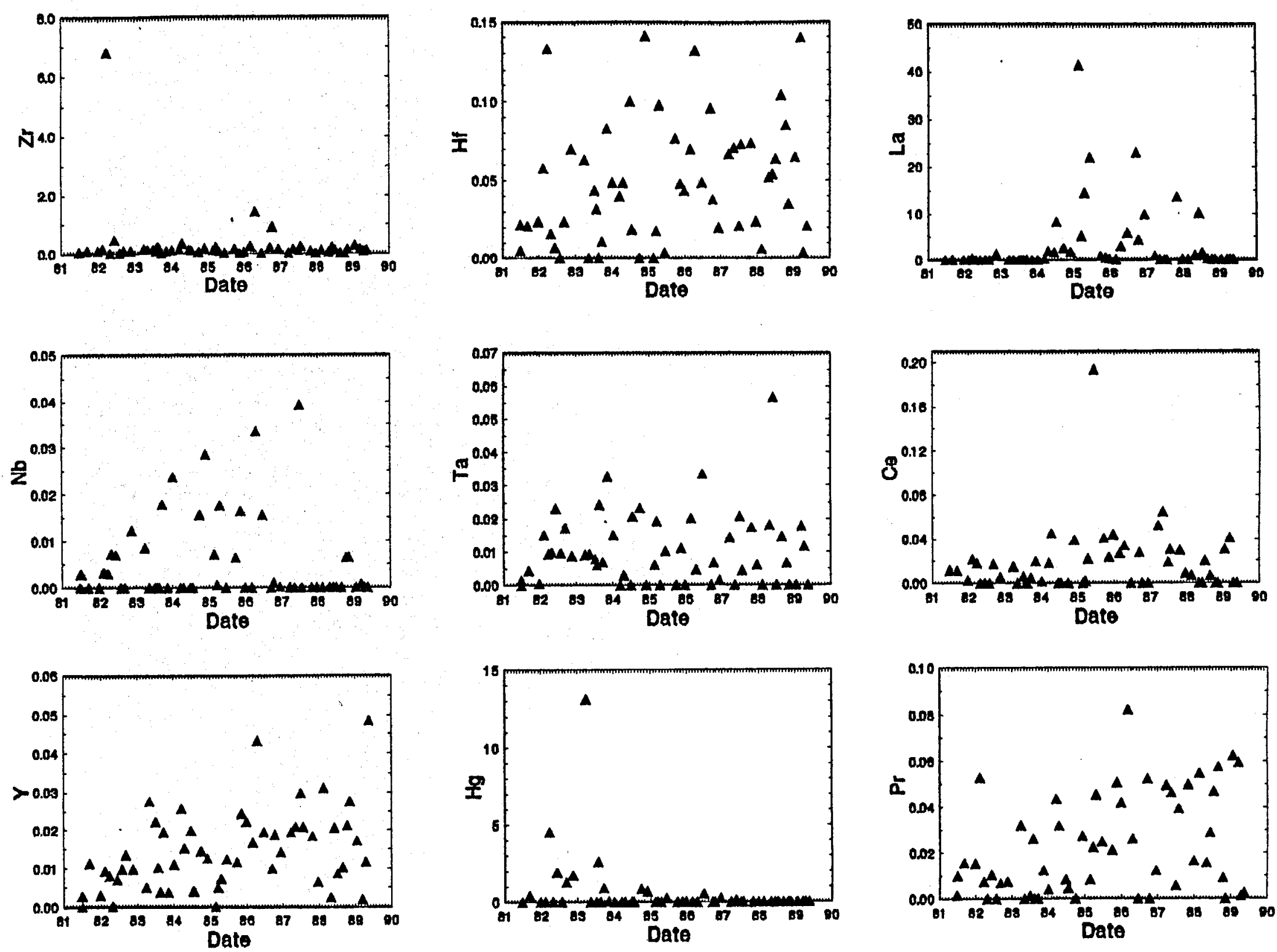

Figure 2 (cont.). Compositions of geothermal fluids from the HGP-A well plotted against the date of sample collection. All samples were collected between 1981 and 1990. 

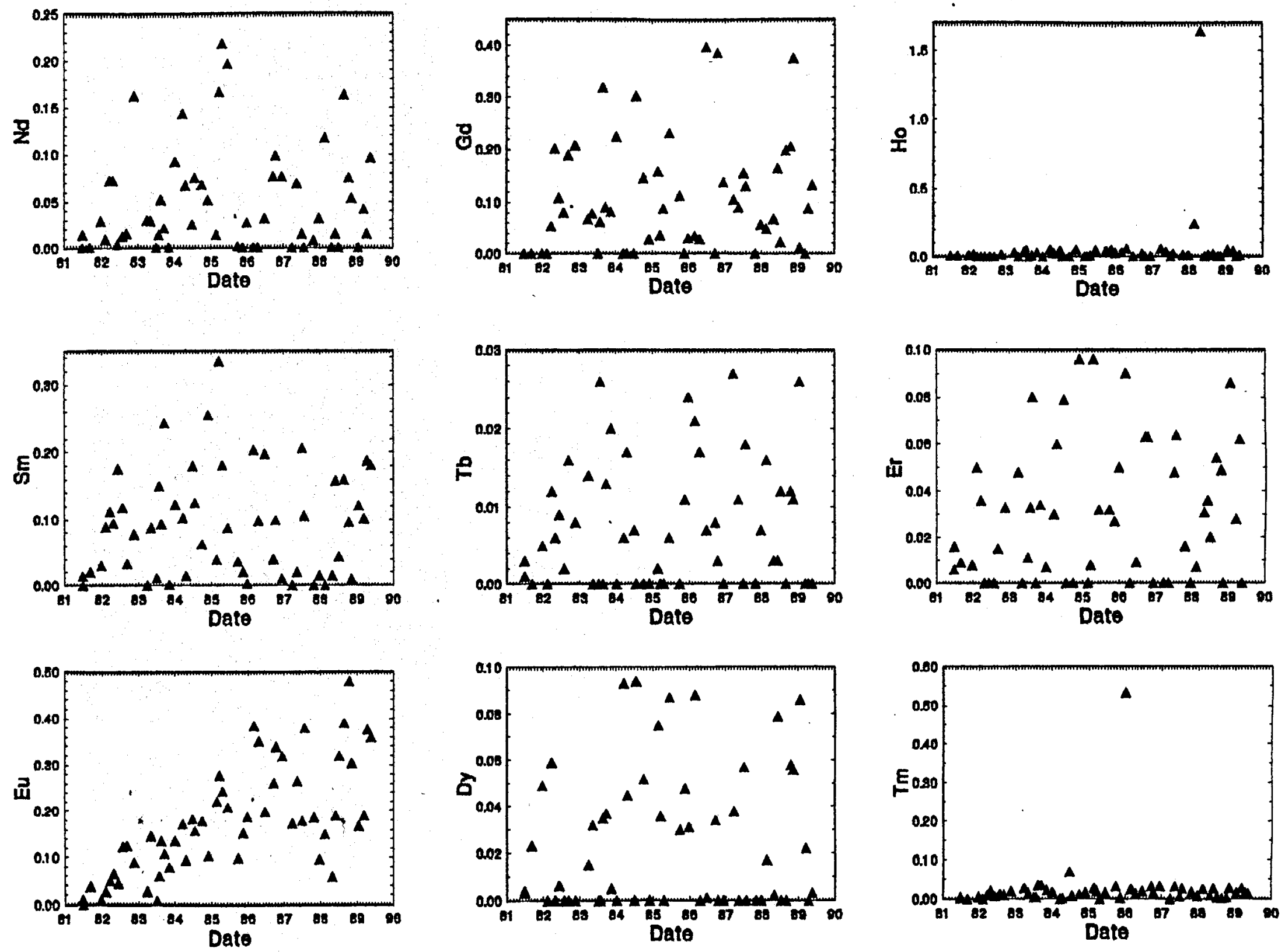

Figure 2 (cont.). Compositions of geothermal fluids from the HGP-A well plotted against the date of sample collection. All samples were collected between 1981 and 1990. 

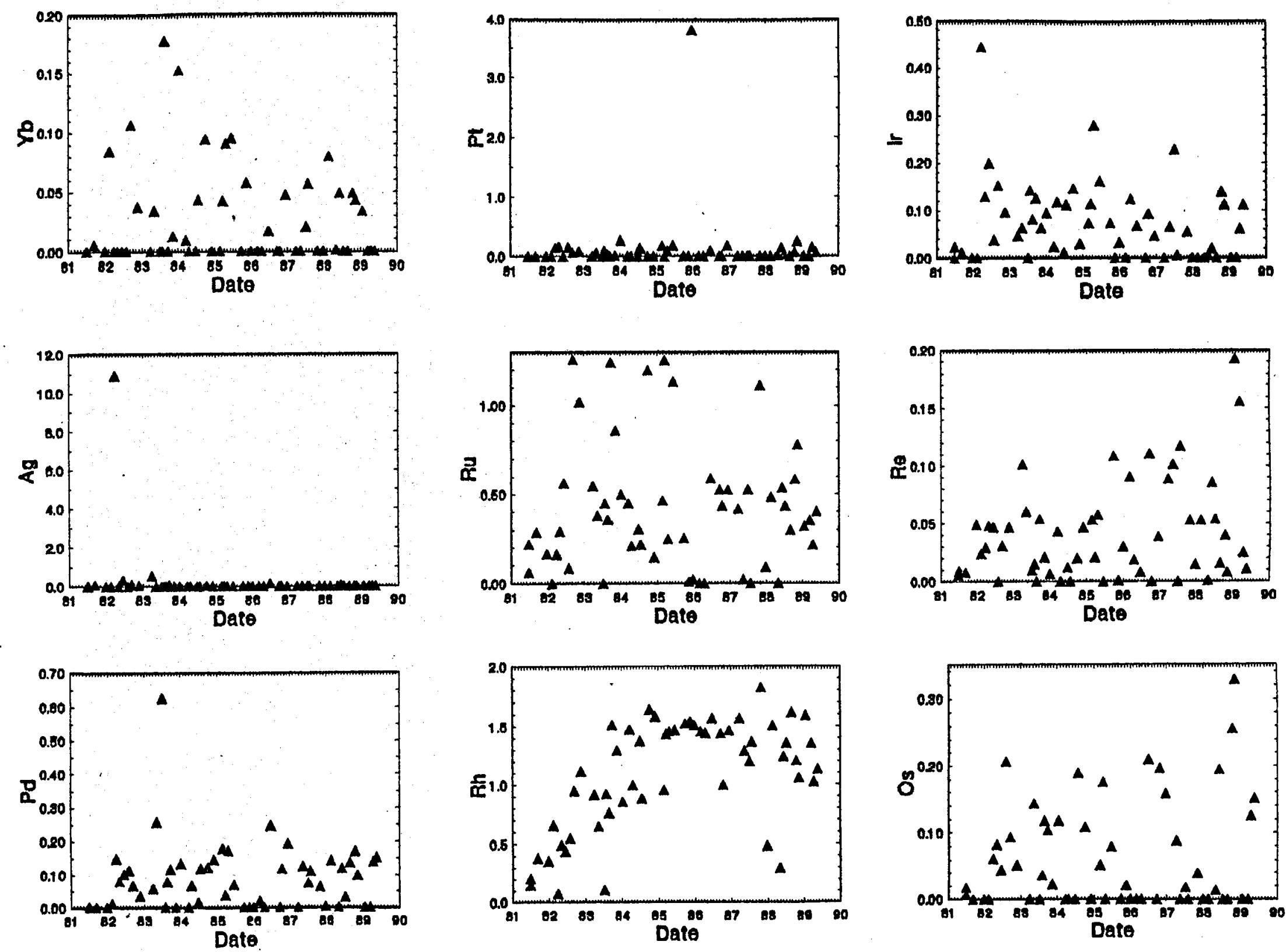

Figure 2 (cont.). Compositions of geothermal fluids from the HGP-A well plotted against the date of sample collection. All samples were collected between 1981 and 1990 . 


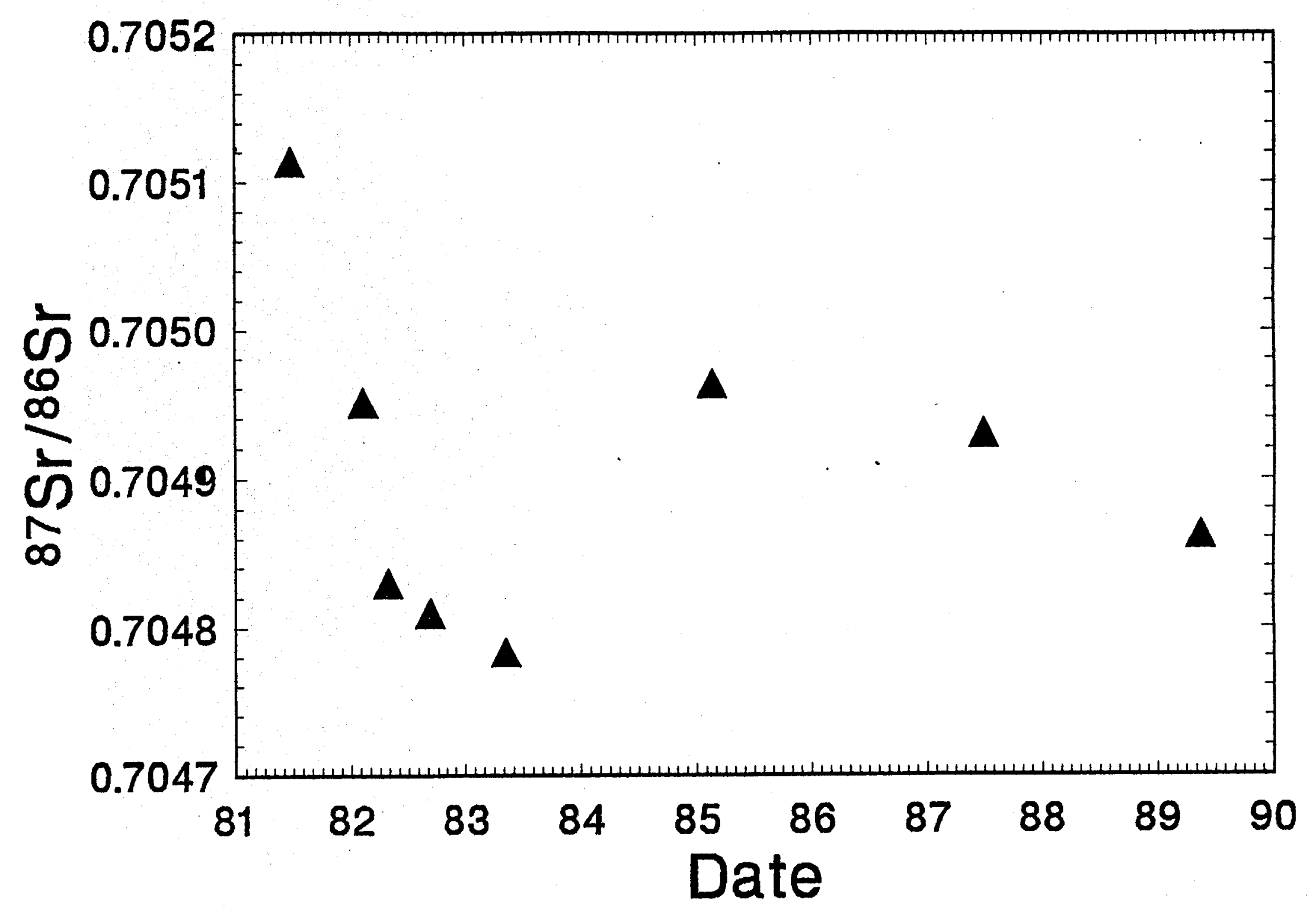

Figure 3. ${ }^{87} \mathrm{Sr} /{ }^{86} \mathrm{Sr}$ versus the date of sample collection for geothermal fluids from the HGP-A well. All samples were collected between 1981 and 1990. 


\section{HGP-A Geothermal Fluids}

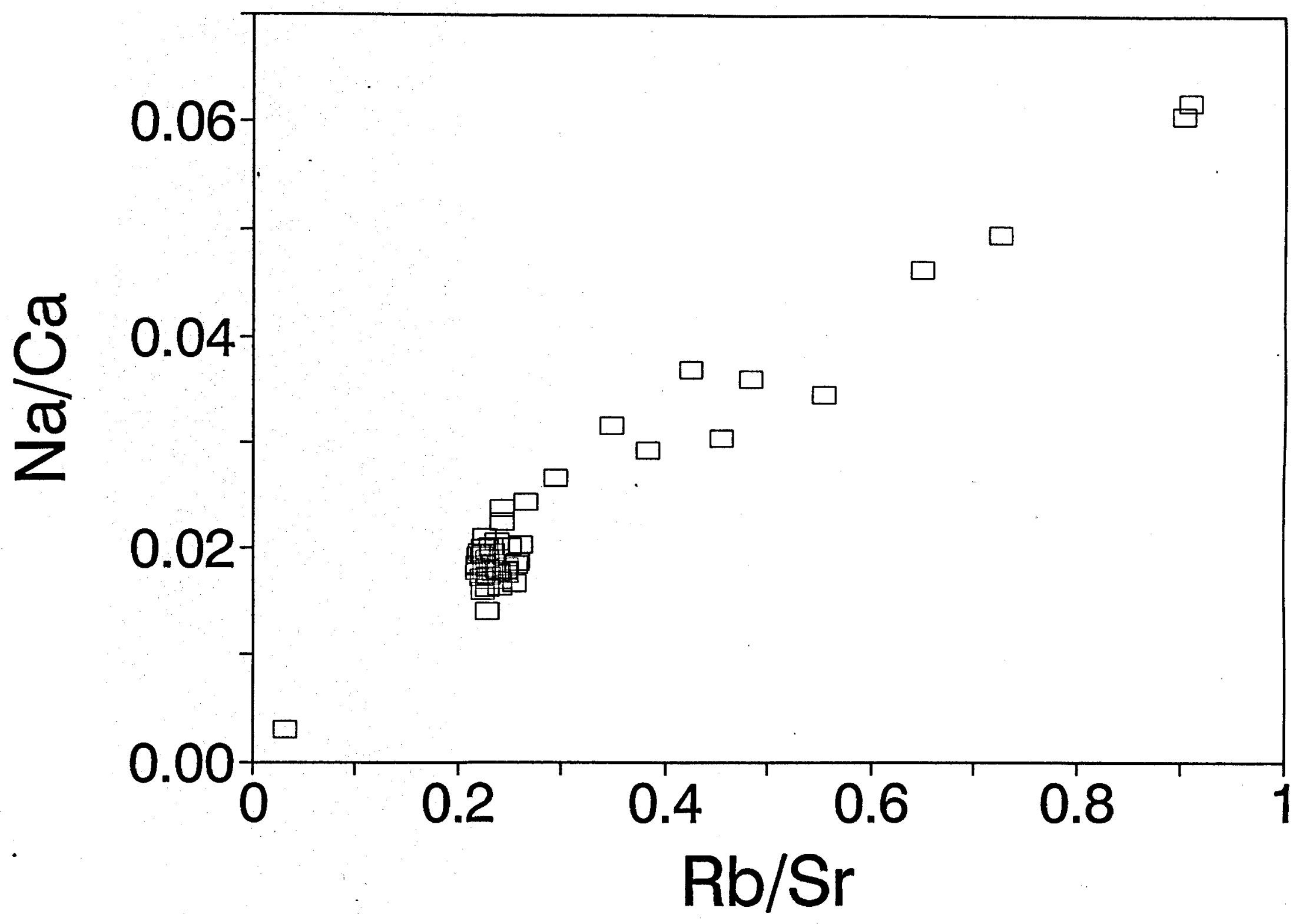

Figure 4. $\mathrm{Rb} / \mathrm{Sr}$ versus $\mathrm{Na} / \mathrm{Ca}$ for geothermal fluids from the HGP-A well. 


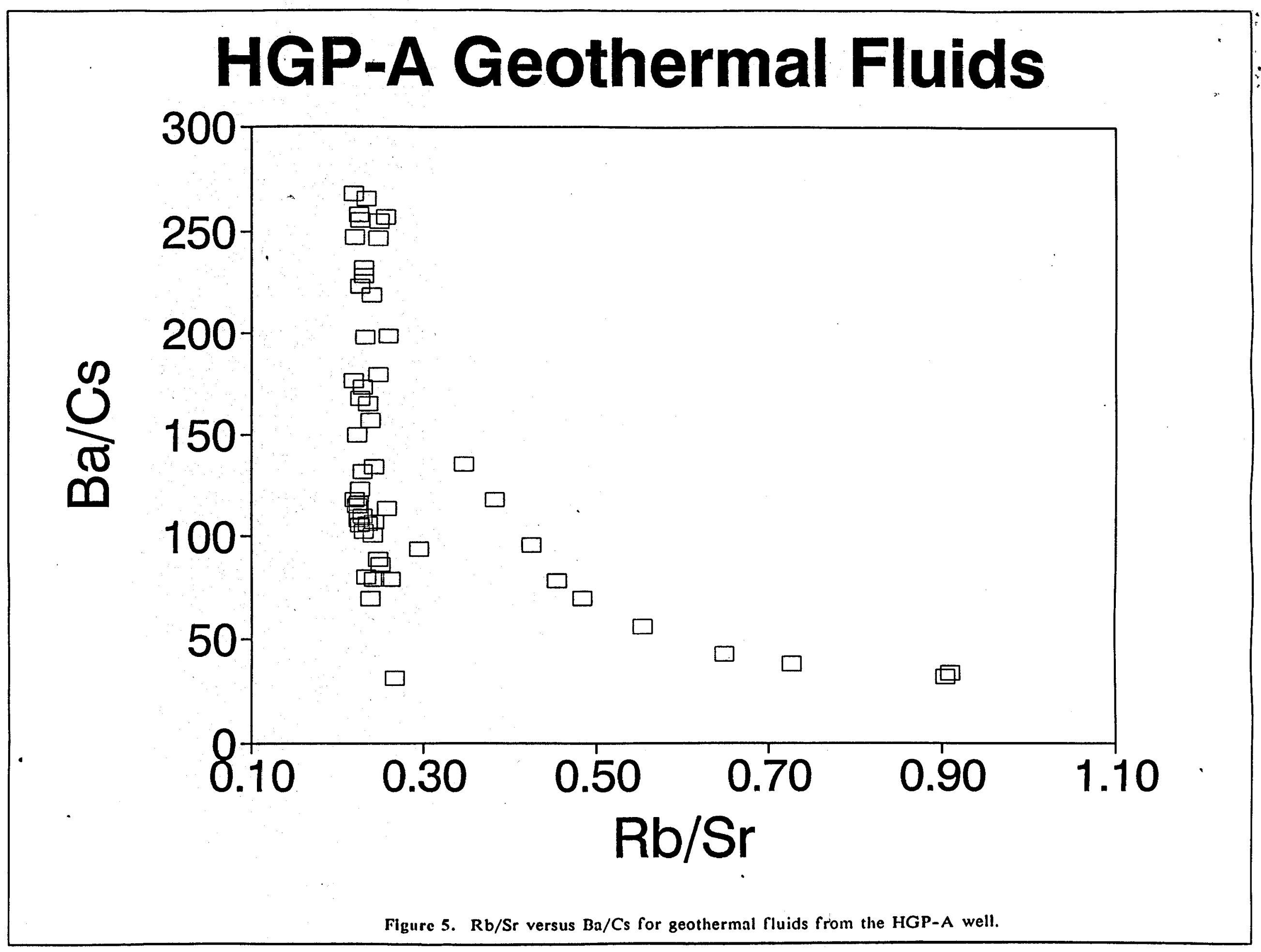




\section{HGP-A Geothermal Fluids}

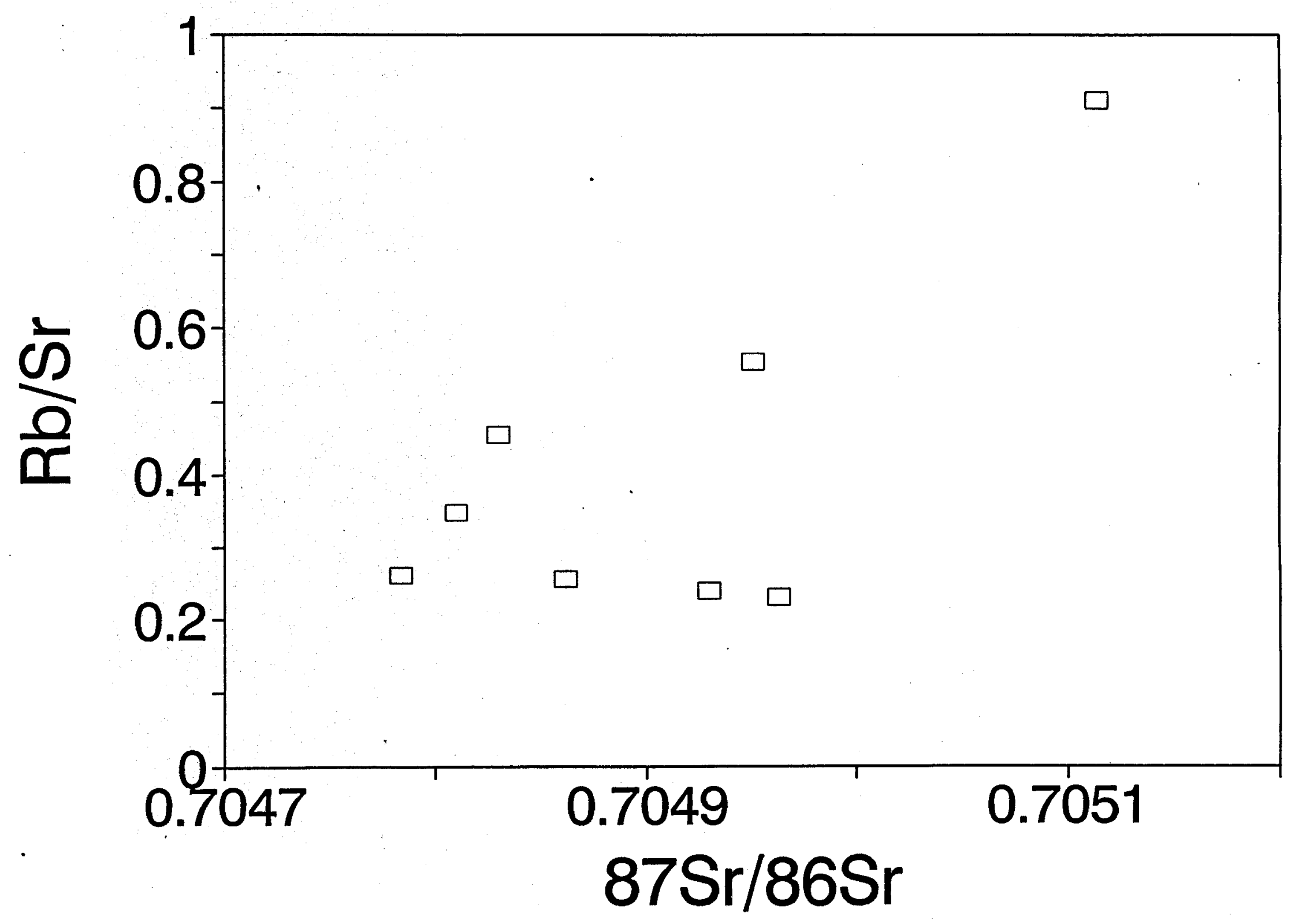

Figure 6. ${ }^{87} \mathrm{Sr} /{ }^{86} \mathrm{Sr}$ versus $\mathrm{Na} / \mathrm{Ca}$ for geothermal fluids from the HGP-A well. 